\title{
A JNK signal transduction pathway that mediates morphogenesis and an immune response in Drosophila
}

\author{
Hayla K. Sluss, ${ }^{1,2}$ Zhiqiang Han, ${ }^{1,2}$ Tamera Barrett, ${ }^{1,2,4}$ Roger J. Davis, ${ }^{1,2,4}$ and Y. Tony Ip ${ }^{1-3,5}$ \\ ${ }^{1}$ Program in Molecular Medicine, ${ }^{2}$ Department of Biochemistry and Molecular Biology, ${ }^{3}$ Department of Cell Biology, \\ University of Massachusetts Medical School, Worcester, Massachusetts 01605 USA; ${ }^{4}$ Howard Hughes Medical Institute, \\ Worcester, Massachusetts 01605 USA
}

\begin{abstract}
The Drosophila MAP kinase DJNK is a homolog of the mammalian c-Jun amino-terminal kinase (JNK). Mutations in the DJNK gene correspond to the complementation group basket. DJNK is phosphorylated and activated by the Drosophila MAP kinase kinase HEP. Substrates of DINK include the transcription factor DJun. DJNK participates in multiple physiological processes. Exposure to endotoxic lipopolysaccharide initiates an insect immune response and leads to DJNK activation. In addition, embryos lacking DJNK are defective in dorsal closure, a process in which the lateral epithelial cells migrate over the embryo and join at the dorsal midline. These data demonstrate that the DJNK signal transduction pathway mediates an immune response and morphogenesis in vivo.
\end{abstract}

[Key Words: MAP kinase; c-Jun amino-terminal kinase; JNK; immune response; dorsal closure]

Received July 3, 1996; revised version accepted September 10, 1996.

The c-Jun amino-terminal kinase (JNK) signal transduction pathway has been implicated in the regulation of gene expression (Dérijard et al. 1994; Kyriakis et al. 1994). Biochemical studies indicate that the effect of JNK to increase gene expression is mediated, in part, by the phosphorylation and activation of the transcription factors c-Jun (Pulverer et al. 1991; Smeal et al. 1991), ATF2 (Gupta et al. 1995; Livingstone et al. 1995; van Dam et al. 1995), and Elk-1 (Cavigelli et al. 1995; Gille et al. 1995; Whitmarsh et al. 1995). Multiple extracellular stimuli, including environmental stress and inflammatory cytokines, activate the JNK protein kinase (Dérijard et al. 1994; Kyriakis et al. 1994; Sluss et al. 1994; Dai et al. 1995; Gupta et al. 1996). Recent studies have indicated that the JNK signaling pathway contributes to the cellular response to environmental stress (Xia et al. 1995; Chen et al. 1996; Verheij et al. 1996). However, the biological role of JNK in the normal development and function of the organism has not been established (Davis 1994).

Exposure of cells to environmental stress causes activation of at least two groups of transcription factors, AP-1 and Rel (Stein et al. 1989). It is established that AP-1 activation is mediated, in part, by the JNK signal transduction pathway (Davis 1994). In contrast, the signaling pathway that activates Rel-related transcription factors during stress has not been established. The Rel

\footnotetext{
${ }^{5}$ Corresponding author.
}

family of transcription factors includes mammalian NF$\mathrm{\kappa B}$ and the Drosophila morphogen Dorsal (Verma et al. 1995). Dorsal is the critical transcription factor that governs the establishment of dorsal/ventral polarity of the embryo (Steward and Govind 1993). The Dorsal-related factor Dif is an important component of the insect immune defense against bacterial infection (Ip et al. 1993) that mediates increased expression of bactericidal peptides, such as Cecropin (Petersen et al. 1995). The Rel family of transcription factors represent conserved molecules that are employed in the immune response of insects and mammals (Ip and Levine 1994). Similarly, AP-1 contributes to the mammalian immune response ( $\mathrm{Su}$ et al. 1994) and may also participate in insect immunity.

We report the identification of a Drosophila homolog of the c-Jun amino-terminal kinase. The DINK protein kinase is activated by endotoxic lipopolysaccharide (LPS). Therefore, DJNK is a component of the insect immune system that is activated in response to bacterial infection. Molecular genetic analysis of the DJNK locus demonstrated that DINK is essential for embryonic development. Loss of DJNK function inhibits the movement of the lateral epithelial cells during mid-embryogenesis and blocks dorsal closure. This defect causes a distinctive cuticle phenotype, identified previously as basket (bsk) (Nüsslein-Volhard et al. 1984). Genetic rescue experiments and sequence analysis provide direct molecular genetic evidence that the bsk locus encodes DINK. This study establishes DJNK as a new member of the MAP kinase group in insects that mediates an im- 
mune response, changes in cell morphology, and cell migration.

\section{Results}

\section{Molecular cloning of Drosophila INK}

A cDNA fragment with sequence homology to JNK was amplified from a Drosophila embryonic cDNA library using degenerate oligonucleotides. This fragment was used to isolate full-length DJNK cDNAs that encode a 372-amino-acid protein with kinase subdomains I-XI (Fig. 1A). The dual phosphorylation motif Thr-Xaa-Tyr, required for MAP kinase activation (Davis 1994), is located in kinase subdomain VIII (Thr-Pro-Tyr). Sequence comparison with other MAP kinases demonstrated that DJNK is a member of the JNK group of protein kinases (Fig. $1 \mathrm{~B}, \mathrm{C}$ ). The amino acid sequence of DJNK is $65 \%$ identical to human JNK1. DJNK is related more distantly to the Drosophila rolled gene product ERKA (Fig. 1C).
A

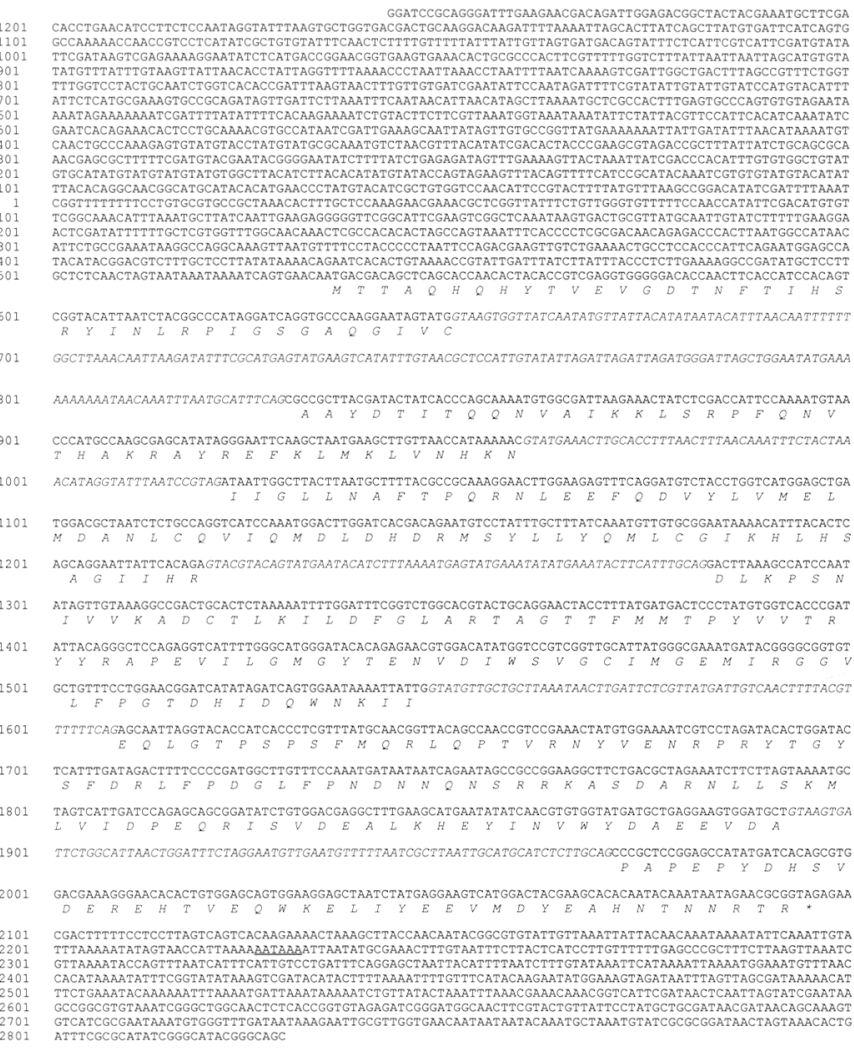

B

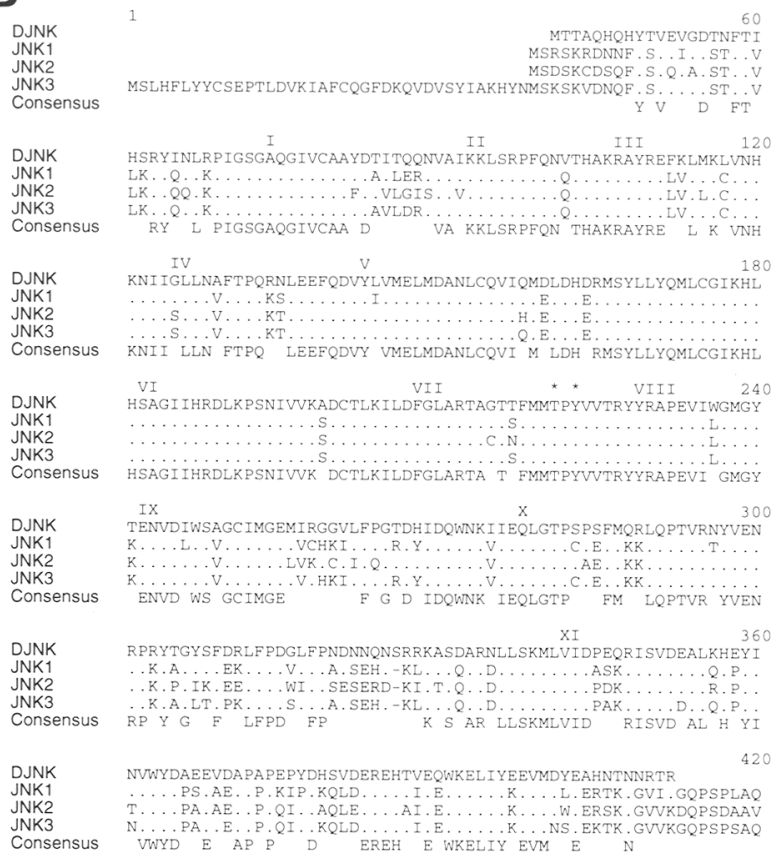

463
Figure 1. Primary structure of the DINK protein kinase. $(A)$ The nucleotide sequence of the DJNK gene is presented. The exon structure of the DJNK gene and the primary sequence of the DJNK protein kinase were deduced from the sequence of cDNA clones. The DJNK sequence is numbered starting with nucleotide 1 of exon 1 . The DINK primary sequence encoded by each exon is illustrated in single letter code (italics). $\left.\right|^{*} \mid$ The termination codon. The polyadenylation site ( $2235 \mathrm{bp}$ ) is preceded by a putative polyadenylation sequence (underlined). The nucleotide sequences of the DINK gene (4186 bp) and the DINK cDNA (1831 bp) have been deposited in GenBank with accession nos. U49249 and U49180, respectively. (B) The DINK primary sequence was compared with human JNK1 (Dérijard et al. 1994), JNK2 (Kallunki et al. 1994; Sluss et al. 1994), and JNK3 (Mohit et al. 1995; Gupta et al. 1996) protein kinases using the PILE-UP program (version 7.2; Wisconsin Genetics Computer Group). The protein sequences are presented in single letter code. (-) Gaps introduced into the sequences to optimize the alignment. Identical residues are indicated with a period. ( $)$ Sites of activating phosphorylation on Thr and Tyr (Dérijard et al. 1994). (C) The relationship between members of the human and Drosophila MAP kinase group is presented as a dendrogram created by the unweighted pair-group method using arithmetic averages (PILE-UP program). The figure presents the analysis of the human MAP kinases ERK1, ERK2, p38 MAP kinase, JNK1, JNK2, and JNK3 (Gonzalez et al. 1992; Owaki et al. 1992; Dérijard et al. 1994; Kallunki et al. 1994; Lee et al. 1994; Sluss et al. 1994; Han et al. 1995; Mohit et al. 1995; Gupta et al. 1996), the Drosophila MAP kinase ERKA (Biggs and Zipursky 1992), and the Drosophila MAP kinase DJNK.

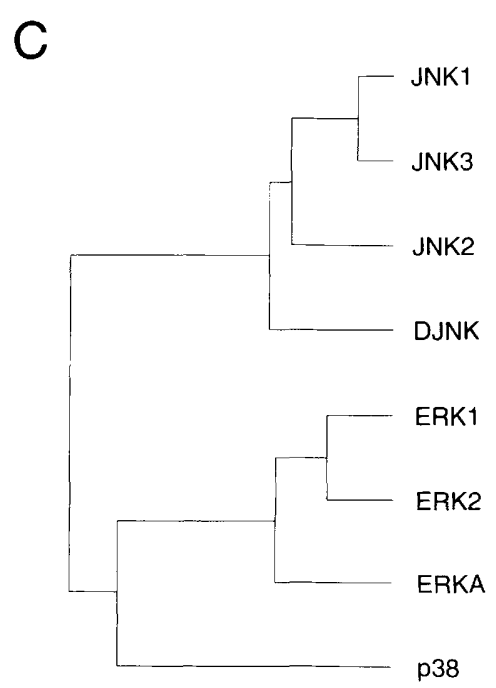




\section{Expression of DINK during embryonic development}

The expression of DJNK was examined using in situ hybridization analysis of embryos at representative developmental stages. A low amount of DJNK staining was detected in early cleavage stage embryos (Fig. 2A). This faint staining appeared in many embryos and may represent expression of maternal mRNA. The zygotic DINK staining is present in all germ layers during germ-band extension (Fig. 2B). During germ-band retraction, the same intense staining remains in the epidermis and the central nervous system (CNS) (Fig. 2C). When dorsal closure begins (Fig. 2D), DJNK staining was increased in the CNS and was present in the lateral epidermal region extending up to the amnioserosa. A stage 15 embryo, when dorsal closure is complete, shows high levels of DINK staining in the ventral nerve chord, the brain, and some peripheral neurons (Fig. 2E). A stage 16 embryo, when the ventral nerve chord has been retracted, also shows a high level of DJNK expression in the nervous system (Fig. 2F). In summary, the zygotic pattern of DINK staining appears to be regulated spatially and temporally. In contrast, the pattern of staining for Drosophila Jun
(DJun) in the developing embryo is ubiquitous (Perkins et al. 1990; Zhang et al. 1990). These physical boundaries of DINK expression, spatial and temporal, may contribute to the regulation of the DJun transcription factor during Drosophila development.

The imaginal discs of the third instar larvae were dissected and hybridized with an antisense DJNK riboprobe. All of these discs stained with the DINK probe (data not shown). The wing disc and eye disc contained high levels of DINK transcripts (Fig. 2G,II). This observation is consistent with a role for DJNK in the differentiation and function of adult tissues.

Northern blot analysis of mRNA extracted from staged embryos demonstrated that the level of DINK expression remained relatively constant throughout embryogenesis (Fig. 3). The predominant mRNA species was $1.8 \mathrm{~kb}$. A second, larger mRNA $(\sim 1.85 \mathrm{~kb})$ was also detected in the early embryo (Fig. 3). The nature of this larger transcript remains to be determined, but it may represent a maternally transcribed product of the DINK gene. DINK was detected in larvae, pupae, and adults (female and male). DINK expression was also detected in the insect fat body and the $m b n-2$ hemocyte cell line


Figure 2. Spatial and temporal distribution of DJNK. $(A-F)$ Various stages of embryos stained with a DJNK antisense riboprobe. The orientation of the embryos is such that anterior is to the left and dorsal is up, unless stated otherwise. $(A)$ An early cleavage stage embryo shows very low levels of DJNK staining. (B) Stage 9 embryo. DJNK staining appears ubiquitous, including the extended germ band and developing anterior and posterior gut. (C) A stage 12 embryo. The focal plane is the lateral surface of the embryo and illustrates the diffuse DJNK staining in the epidermis. The predominant staining is in the developing CNS. (D) A stage $14 \mathrm{em}-$ bryo. The germ band has retracted and DINK staining is present in the CNS and in the epidermis extending up to the amnioserosa. $(E)$ Stage 15 embryo. Dorsal closure is complete and the germ band has shortened. DJNK staining is restricted to the ventral nerve chord, brain, and some peripheral neurons. (F) Stage 16 embryo (ventral view). The ventral nerve chord has undergone shortening. This is a ventral view to show the staining of the nerve chord, underlying brain, and peripheral neurons. $(G-I)$ Imaginal discs stained with a DINK riboprobe. $(G)$ Wing imaginal disc stained with a DINK antisense riboprobe. $(H)$ Eye imaginal disc stained with a control sense DJNK riboprobe and $(I)$ an antisense DJNK riboprobe. Both imaginal discs contain broad DJNK staining. 


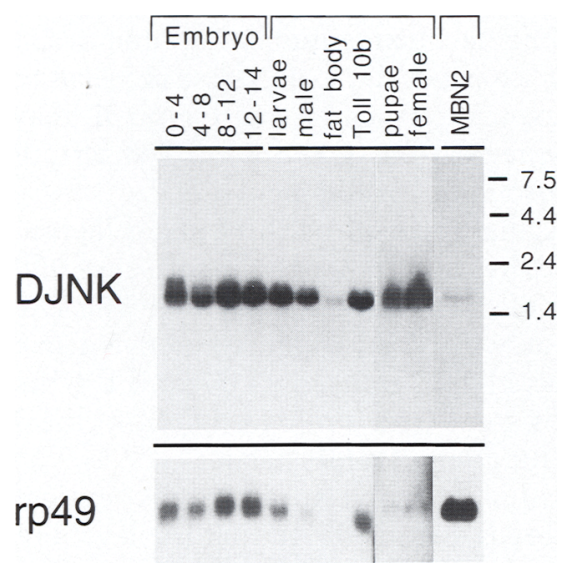

Figure 3. DINK expression during embryonic development and in various tissues. Northern blot analysis of poly $(\mathrm{A})^{+}$RNA was performed using a random-primed, full-length, DINK cDNA probe. (Left) Embryo (15 $\mu \mathrm{g}$ RNA) at 0-4, 4-8, 8-12, 12-14 hr. (Middle) Larvae (10 $\mu \mathrm{g})$, adult male $(5 \mu \mathrm{g})$, fat body (2 $\mu \mathrm{g})$, Toll $10 \mathrm{~b}$ larvae $(15 \mu \mathrm{g})$, pupae $(15 \mu \mathrm{g})$, and adult female (15 $\mu \mathrm{g})$. (Right $)$ Cultured $m b n-2$ hemocytes $(30 \mu \mathrm{g})$. The migration of the RNA size markers is indicated on the right (in $\mathrm{kb}$ ). The blots were reprobed for $\mathrm{rp} 49 \mathrm{mRNA}$ to control for variations in RNA loading (bottom)

(Fig. 3). The fat bodies and hemocytes are the primary immune organs of the insect (Engström 1993; Hoffmann et al. 1993; Hultmark 1993).

\section{DINK locus in wild-type and deficiency strains}

To elucidate the role of DJNK in Drosophila developmental and physiological processes, we conducted a molecular genetic analysis of the DJNK genomic locus. Hybridization analysis demonstrated that the DJNK gene lies on the left arm of the second chromosome in the 31B-C interval (Fig. 4A). Several Jammed-derived deficiencies in the $31 \mathrm{~B}-\mathrm{C}$ region were analyzed for DJNK expression and genomic lesions. One lammed line, $D f(2 L) J R 1$, was found by chromosome in situ hybridization analysis to delete the entire DINK gene (data not shown). Embryos were collected from the IR1 line, which was carried over the $\mathrm{CyO}$ balancer chromosome, and RNA in situ hybridization analysis was performed. Approximately one-quarter of the embryos (the expected inheritance) did not stain for DJNK mRNA (Table 1). Two other Jammed-derived deletions, 1106 and 177, showed normal DJNK staining (Table 1).

The $M E 31 B$, flipper $(f l p)$, and Dror genes have been localized previously to the distal part of $31 \mathrm{~B}-\mathrm{C}$ region (Valoir et al. 1992; Wilson et al. 1993). Sequence analysis of a DINK genomic clone revealed that it contained the $M E 31 B$ open-reading frame (ORF) in an orientation that was opposite to DJNK (Fig. 4B). Therefore, DINK is located adjacent to ME31B. Embryos were collected from flp-derived deficiency lines and stained for DJNK mRNA. One-quarter of the embryos from these lines did not have DJNK staining, consistent with the expected inheritance (Table 1). Southern blot analysis was performed to confirm the lesions within the DINK gene. The deficiency $f l p 170 B$ probably deletes the entire DJNK gene. Similarly, the deficiency flp170E disrupts expres-
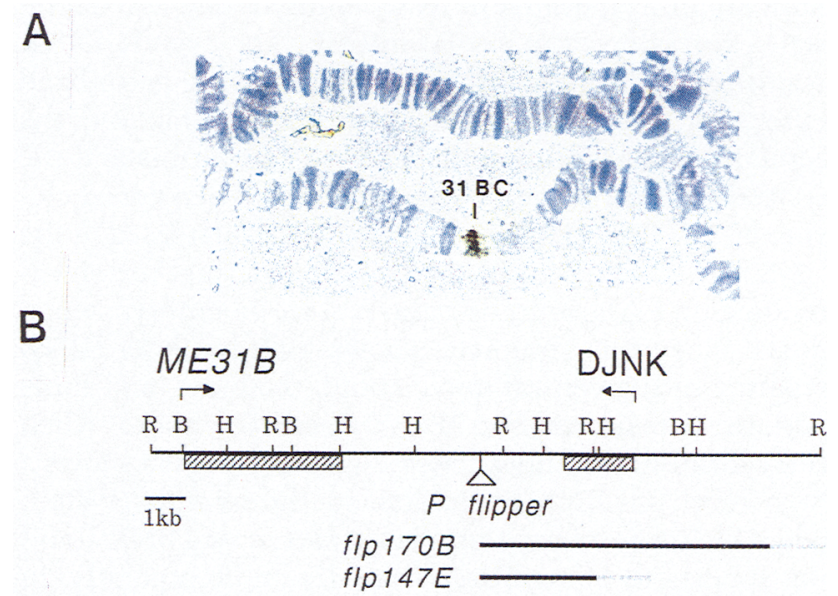

C
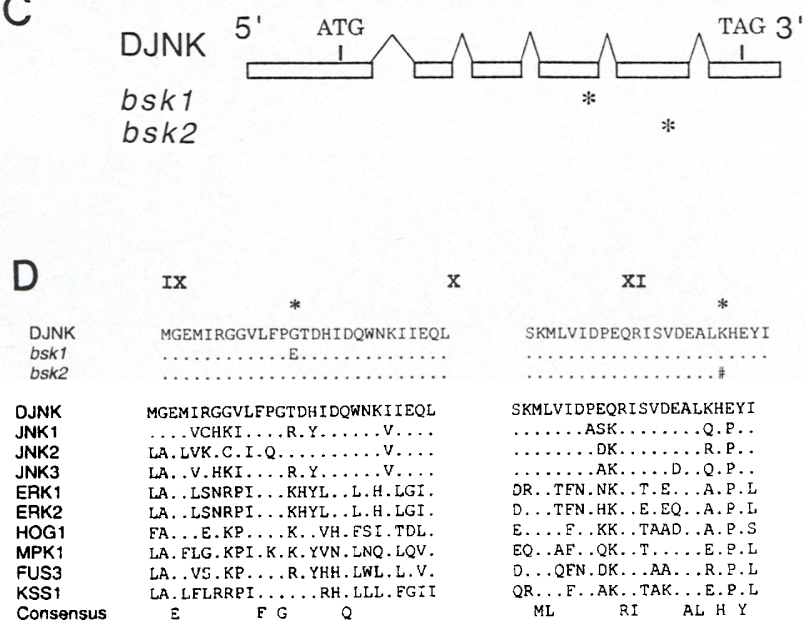

Figure 4. Genomic organization of the DJNK locus. $(A)$ In situ hybridization of a DINK probe with polytene chromosomes from the salivary gland. The DINK gene maps to the left arm of chromosome 2, region $31 \mathrm{~B}-\mathrm{C}$. The line indicates the specific DJNK staining. (B) Schematic illustration of the DINK locus. The arrows indicate the direction of transcription. The DINK gene is marked by a hatched box. The DJNK gene is located next to the $M E 31 B$ gene and the P-element insertion flp. DJNK is deleted in the strains flp147E and flp170B, the deletions are represented by lines. The breakpoints of the deficiencies are not precisely defined and are represented by hatched lines. $(C)$ Schematic representation of the intron/exon structure of the DINK gene. $\left({ }^{*}\right)$ The two bsk alleles, corresponding to the mutations in the DJNK gene. bsk1 has a point mutation in codon 225; GGA (Gly) is replaced with GAA (Glu). bsk2 has a point mutation at codon 316, AAG (Lys) is replaced by TAG (stop). The sequence of the bsk1 and bsk2 genes has been deposited in GenBank under accession nos. U50965 and U50966, respectively. (D) The primary sequence surrounding the bsk mutations (kinase subdomains IX-X and subdomain XI) is presented. (\#) The stop codon in $b s k 2$. These regions are compared with the sequence of other members of the MAP kinase group. 
Table 1. Correlation between loss of DINK function and defects in dorsal closure

\begin{tabular}{lcc}
\hline & DINK mRNA & Dorsal closure \\
\hline Canton $S$ & + & + \\
$D f(2 L) / R 1$ & - & - \\
$D f(2 L) / 77$ & + & + \\
$D f(2 L) / 106$ & + & + \\
flp147E & - & - \\
flp170B & - & - \\
bsk1 & + & - \\
bsk2 & + & - \\
\hline
\end{tabular}

DJNK mRNA staining was judged by in situ hybridization with a DJNK riboprobe. A total of 500 embryos were scored for DJNK staining. The parent flies are heterozygous and the recessive trait has an expected inheritance of $25 \%$. Strains with $>95 \%$ embryos staining for DJNK were scored as positive $(+1$. Strains with $\sim 25 \%$ embryos without DJNK staining were scored negative $(-)$. The presence $(+)$ or absence $(-)$ of complete dorsal closure was examined in embryo collections $(0-12 \mathrm{hr})$ of each strain. The embryos were aged and the cuticles of unhatched embryos were examined. Fly lines were scored positive $(+)$ if none of the unhatched embryos had defects in dorsal closure and negative $(-\mid)$ if $>20 \%$ of the embryos exhibited defects in dorsal closure (or $5 \%$ for $b s k 2$ ). The $b s k 1$ and $b s k 2$ flies contain mutations within the DINK coding region that do not alter mRNA expression (Fig. 4D).

sion of DJNK mRNA and probably contains a breakpoint within the DJNK gene. A schematic representation of the genomic organization of the DINK locus within the 31B-C region is shown in Figure 4B.

\section{Loss of DINK function correlates with defective dorsal closure}

The lammed and flp deficiencies were examined for abnormalities in cuticle morphology. Embryos were collected from the deficiency strains and aged for 24-36 hr. Cuticles of the unhatched embryos were prepared. For all the deficiencies that deleted DINK, examination of the cuticles of unhatched embryos revealed a population with an aberrant dorsal cuticle (Fig. 5). These lines produced a population of dead embryos with a range of mutant dorsal cuticle phenotypes (Fig. 5B,C). The severely deformed cuticles had a dramatic reduction in dorsal ridge formation, with the head and anterior segments exposed (Fig. 5B). In other embryos, holes in the dorsal epidermis are observed. The size of the hole varies from a large hole that covers most of the dorsal region (Fig. 5B) to a small hole (Fig. 5C). The deficiency lines where DINK expression was normal did not contain defects in the dorsal cuticle (Table 1).

Careful examination of the mutant embryos indicated no defects in tissue differentiation (data not shown). Both the amnioserosa and epidermis are present, suggesting that dorsoventral patterning is not defective. Furthermore, the morphogenetic processes of gastrulation, germ-band extension, and germ-band retraction occur normally. We postulate that the hole in the dorsal cuticle was the result of defective dorsal closure during midembryogenesis. During this process, the lateral epithelial cells move as a sheet to cover the dorsal region of the embryo (MacKrell et al. 1988; Ashburner 1989; Ring and Martinez Arias 1993; Young et al. 1993; Fehon et al. 1994). There is no new cell division. Instead, the cells change morphology and migrate. The cells at the leading edge undergo elongation, beginning at germ-band retraction. Subsequently, more cells undergo this morphological change concomitantly with spreading (MacKrell et al. 1988; Ring and Martinez Arias 1993; Young et al. 1993; Fehon et al. 1994). A contiguous layer of cells forms, which results in the closure of the epidermis over the amnioserosa and internal organs.

\section{DINK rescues the bsk phenotype}

The correlation between DINK function and dorsal closure led us to examine the complementation group bsk that is defective in dorsal closure and maps to the 31B-F region (Nüsslein-Volhard et al. 1984). We obtained two alleles of $b s k$ (bsk1 and $b s k 2$ ) from the Nüsslein-Volhard laboratory for analysis. Cuticle examination demonstrated that the bsk embryos exhibit a defect in dorsal closure that is similar to the Jammed and flp deficiencies (Table 1; Fig. 5D). Both severely defective cuticles (Fig. 5D) and cuticles with holes (Fig. 5E, F) were observed. The defect in both bsk alleles is similar, except that more cuticles with a severe phenotype were observed for $b s k 1$ than $b s k 2$. To identify the genetic location of $b s k$, we crossed the bsk alleles with flp170B and flp147E. Complementation was not observed in the trans-heterozygous embryos (data not shown). This finding suggests that bsk is located in the same small chromosomal region as DJNK.

To obtain evidence that bsk encodes DJNK and participates in the dorsal closure pathway, a genetic rescue experiment was conducted. The DJNK cDNA was placed under the control of a heat shock promoter (hsDJNK) and introduced into the fly genome through P-element-mediated transformation. Nine independent transgenic lines were generated. All of these lines have induced expression of DJNK under heat shock. Control experiments demonstrated that overexpression of the wildtype DJNK protein did not lead to a defect in embryonic development (data not shown). The chromosomal locations of the transgenes were determined and flies with the P-element located on the $\mathrm{X}$ or third chromosome were mated with the $b s k 1$ and $f l p 170 B$ flies. Balanced fly stocks were obtained and used to determine if the expression of DJNK could rescue the embryonic lethality or reduce the cuticular lesion.

We found that hsDINK rescued the dorsal closure phenotype of $b s k 1$ and flp170B (Table 2). Embryos were collected from $f l p 170 B ; h s D I N K$ and $b s k 1 ;$ hsDINK and aged until hatching. The cuticle structure of the unhatched embryos was examined. There was a marked reduction in dorsal closure defects. The flp170B; hsDINK and 
Figure 5. Effect of DJNK on dorsal closure. Comparison of the cuticles of wild-type flies and flies with DINK defective alleles or $h s D$ $I N K$ rescue alleles. The orientation is such that anterior is up. $(A)$ Wild-type cuticle illustrating the regular spacing of the denticle belt on the ventral side (left) and complete closure of the epidermis on the dorsal side (right). (B) A flp170B cuticle which shows a severe defect in dorsal closure. (C) A $f l p 170 B$ cuticle (dorsal view) in which dorsal closure began and then terminated leaving a medium size hole. $(D) \mathrm{A}$ bsk 1 cuticle illustrating a severe defect in dorsal closure. (E) A bsk1 cuticle exhibiting a less severe defect in dorsal closure. $(F)$ A bsk 1 cuticle (dorsal view) with a moderate defect that results in a small hole. (G) A flp170B; hsDINK cuticle illustrating that the severity of the defect has been reduced. $(H) \mathrm{A} b s k 1$; $h s D I N K \mathrm{cu}-$ ticle that appears to be wild-type. (I) A bsk1; $h s D / N K$ embryo showing rescue of the dorsal defect, but leaving a tiny hole.
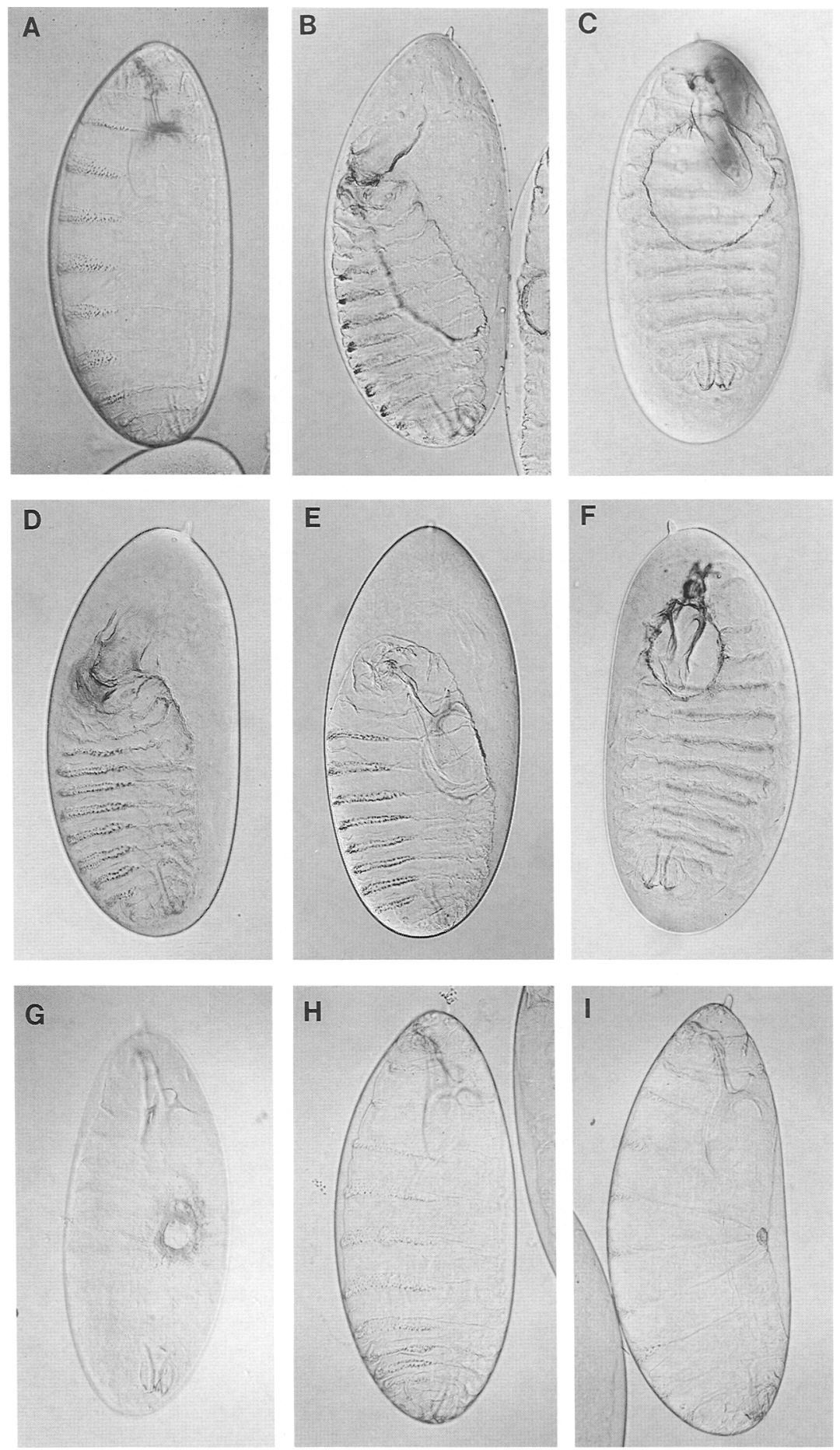

bsk1; hsDINK lines contained very few cuticles with a severe defect in dorsal closure (Table 2). The number of flp170B; $h s D / N K$ cuticles with defective dorsal closure was greatly reduced $(2 \%)$ compared with the $f l p 170 B$ line $(23 \%)$. Furthermore, the cuticles presenting defects had a less severe phenotype (Fig. 5G). Wild-type cuticles were observed in the remainder of the unhatched embryos. In the $b s k 1$; hsDINK line, most of the unhatched embryos had wild-type cuticles (Fig. 5H). Some unhatched embryos contained just a pinhole and appeared to develop to a later stage (Fig. 5I). These tiny holes were not apparent in the parent bsk 1 line. Only $1 \%$ of the bsk 1 ; hsDINK embryos exhibited defective cuticles compared with $22 \%$ of the bsk 1 parental line. For both rescued lines (flp170B; hsDINK and bsk1; hsDINK), there was no significant reduction in the total number of unhatched em- 
Table 2. Analysis of DINK complementation on dorsal closure

\begin{tabular}{lcc}
\hline & Basket cuticles $(\%)^{\mathrm{a}}$ & Dead embryos $(\%)^{\mathrm{b}}$ \\
\hline flp170B & 23 & 35 \\
flp170B; hsDINK & 2 & 25 \\
bsk1 & 22 & 28 \\
bsk1; hsDINK & 1 & 18 \\
\hline
\end{tabular}

Independent $h s D / N K$ lines were crossed with bsk 1 and $f l p 170 B$ flies. Two lines required heat shock during early to mid-embryogenesis to rescue the cuticle defect of bsk1 and $f 1 p 170 B$. Three additional hsDINK lines rescued without heat shock treatment; the data obtained for one hsDINK lines are shown. Five hundred embryos from heterozygous mutant parents were collected and aged until hatching.

${ }^{a}$ The cuticles of the unhatched embryos were examined. The number of basket cuticles (including severe, medium hole, and small hole; Fig. $5 \mathrm{~B}-\mathrm{F}$ ) is presented as a percentage of the total embryos collected.

${ }^{\mathrm{b}}$ The percentage of unhatched embryos compared with total embryos is presented.

bryos. Therefore, DJNK is probably required for other developmental processes and the $h s D I N K$ transgene may not provide correct DINK expression for complementation of these other functions. We conclude from these genetic rescue experiments, that the dorsal closure phenotype exhibited in the deficiencies and the bsk alleles is attributable to the loss of DJNK function.

\section{bsk alleles encode mutant DINK}

RNA in situ hybridization analysis of bsk embryos demonstrated that DJNK expression appears to be normal (Table 1). We therefore postulated that the mutations that contribute to the loss-of-function are present within the coding region of DINK. The wild-type DJNK gene consists of six exons and five introns (Fig. 4C). Sequence analysis demonstrated that the bsk 1 allele encodes a mutated DINK protein with a substitution of Glu for Gly at codon 225. The G225E mutation is located between subdomains IX and X of the DJNK protein kinase (Fig. 4D). Gly-225 is conserved in the MAP kinase family and is located in a region identified to be required for substrate recognition by JNK protein kinases (Kallunki et al. 1994; Sluss et al. 1994; Dai et al. 1995; Gupta et al. 1996). The bsk2 allele encodes a truncated DINK protein kinase that results from the presence of a termination codon within kinase subdomain XI (Fig. 4D). These substitution and truncation mutations in the DJNK gene provide strong evidence that DINK is encoded by bsk. We conclude that dorsal closure requires signaling by the DJNK protein kinase.

\section{Biochemical properties of DINK}

A Drosophila MAP kinase kinase homolog, Hemipterous (HEP), was identified recently and demonstrated to be required for dorsal closure (Glise et al. 1995). The HEP sequence is most similar to the stress-activated mammalian MAP kinase kinases MKK3, MKK4, and MKK6 (Sanchez et al. 1994; Dérijard et al. 1995; Lin et al. 1995; Raingeaud et al. 1996). In hep ${ }^{-}$embryos, the lateral epidermal cell movement during dorsal closure is suppressed and a defect in dorsal closure is observed. Because the loss of DJNK function also causes defective dorsal closure, it is possible that DINK and HEP may function in the same signal transduction pathway. To test this hypothesis, we examined whether DINK is phosphorylated and activated by HEP. Both protein kinases were prepared as recombinant proteins in bacteria and purified (Fig. 6A). HEP and DINK do not appreciably autophosphorylate (Fig. 6A, lanes 1 and 2). However, when HEP and DJNK are incubated together, there is marked phosphorylation of both proteins (Fig. 6A, lanes 3 and 6). This observation indicates that DINK is a substrate for HEP and that, like mammalian MKK4 (Dérijard et al. 1995), HEP is a substrate for activated DINK (Fig. 6A). To determine whether the phosphorylation of DJNK by HEP leads to DINK activation, the protein kinase activity of DINK was measured. Mammalian INK phosphorylates the c-Jun transcription factor on the activating sites Ser-63 and Ser-73 (Pulverer et al. 1991; Smeal et al. 1991). A c-Jun homolog in Drosophila (DJun) that is expressed throughout development has been identified (Perkins et al. 1988; Perkins et al. 1990; Zhang et al. 1990). The sites of phosphorylation on c-Jun, corresponding to Ser-63 and Ser-73, are conserved in DJun. In vitro protein kinase assays demonstrated that the DINK protein kinase phosphorylates both c-Jun (data not shown) and DJun (Fig. 6A). Addition of HEP caused a large increase in the phosphorylation of DJun by DJNK (lane 6). These data demonstrate that DJNK is phosphorylated and activated by HEP (Fig. 6A) and provide biochemical evidence that HEP and DJNK are components of a MAP kinase signal transduction pathway.

\section{DINK is activated during the response to endotoxin}

Mammalian JNK has been implicated in a variety of immunity-related signaling pathways, including the response to pro-inflammatory cytokines, the response to endotoxic LPS, and T-cell activation (Dérijard et al. 1994; Kyriakis et al. 1994; Sluss et al. 1994; Su et al. 1994; Westwick et al. 1994; Raingeaud et al. 1995; Whitmarsh et al. 1995|. Previous studies have demonstrated that insects and mammals employ homologous molecules to mediate immune responses (Engström 1993; Hoffmann et al. 1993; Hultmark 1993; Ip and Levine 1994). We therefore tested whether DINK contributes to an immune response. Bacterial infection causes insect immune tissues to synthesize a spectrum of antibacterial peptides, including Cecropin and Diptericin, which lyse the invading microorganisms (Hultmark 1993). The response to bacterial infection can be studied by examining the effect of LPS, a component of the bacterial cell wall. Addition of LPS to Drosophila cultured cell lines, including $m b n-2$ hemocytes and Schneider S2* embryonic cells, causes marked induction of cecropin and dip- 


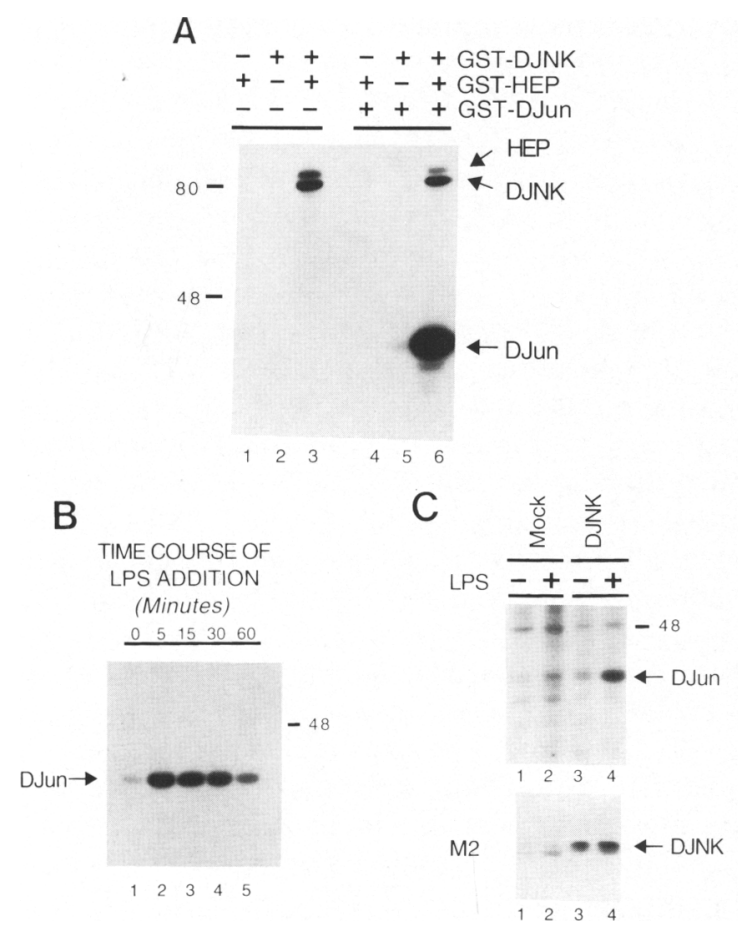

Figure 6. Regulation of DINK protein kinase activity. (A) Recombinant HEP was used to phosphorylate and activate DJNK in the presence and absence of the DINK substrate DJun. (Lanes 1-3) Without the DJNK substrate GST-DJun; (lanes 4-6) with GST-DJun. The samples were examined by PAGE and autoradiography. The numbers on the left represent protein mass markers in $\mathrm{kd} .(B)$ Time course of DINK protein kinase activation by LPS. The mbn-2 hemocytes were treated with LPS $(10$ $\mu \mathrm{g} / \mathrm{ml}$ ) for the time indicated. The cells were harvested and the endogenous DJNK protein kinase activity was measured in an immune complex kinase assay using a polyclonal antibody to INK and the substrate GST-DJun. The numbers on the right represent protein mass standards in $\mathrm{kd} .(C)$ Treatment with LPS causes increased activity of epitope-tagged DJNK. S2 * cells were mock-transfected (lanes 1 and 2) or transfected with the Flag-DINK expression vector (lanes 3 and 4). LPS $(10 \mu \mathrm{g} / \mathrm{ml})$ was added to the cells for $15 \mathrm{~min}$. (Top) DJNK protein kinase activity was measured in an immunecomplex kinase assay with the M2 monoclonal antibody (anti-Flag) with the substrate GST-DJun. (Bottom) The expression of Flag-DJNK was examined by protein immunoblot analysis of transfected S2* cell lysates using the M2 antibody. The numbers on the right represent protein mass standards in kilodaltons.

tericin genes (Reichhart et al. 1992; Samakovlis et al. 1992; Engström et al. 1993; Kappler et al. 1993).

The effect of LPS treatment on DJNK protein kinase activity was examined. Hemocytes (mbn-2 cells) were treated with LPS at a concentration $(10 \mu \mathrm{g} / \mathrm{ml})$ that is optimal for the induction of the immunity genes cecropin and diptericin (Engström et al. 1993; Kappler et al. 1993). The cells were harvested after different times of incubation with LPS and the endogenous DJNK was immunopurified with a polyclonal antibody to human JNK. In vitro protein kinase assays were performed with the substrate DJun (Fig. 6B). DJNK was activated within 5 min of LPS addition. However, DJNK activation was transient and returned to basal levels after $1 \mathrm{hr}$ (Fig. 6B). To confirm that the cloned DJNK protein kinase was activated by LPS, we expressed epitope-tagged DJNK (Flag-DJNK) in S2* cells. The expression of Flag-DINK was confirmed by Western blotting with the M2 monoclonal antibody to the Flag epitope (Fig. 6C). Immune complex kinase assays demonstrated that LPS activated the epitope-tagged DJNK in S2* cells (Fig. 6C). Together, these data indicate that LPS causes rapid activation of DJNK, suggesting that DJNK targets an early event in the response to endotoxin. Mammalian JNK protein kinase activity and AP-1 transcriptional activity are increased during the immune response (Su et al. 1994). By analogy, we propose that the activation of DJun by DJNK in LPS-treated insect cells may lead to increased AP-1 transcriptional activity. Targets of Drosophila AP-1 may include the DJun promoter (Zhang et al. 1990; Wang and Goldstein 1994) and other genes related to an immune response (Engström 1993; Hoffmann et al. 1993; Hultmark 1993; Ip and Levine 1994). Genetic analysis of immune responses in bsk animals is, however, confounded by the embryonic lethality of the DINK mutation. As the larval fat body cells grow by endoreplication, a method to achieve mitotic recombination in the fat body precursor cells is required. A goal of future studies will be to develop methods for the genetic analysis of DINK function during immune responses.

\section{Discussion}

Previous studies of Drosophila have led to the identification of one MAP kinase, encoded by rolled (ERKA), that mediates receptor tyrosine kinase signaling, including the torso, DER, and sevenless pathways (Biggs et al. 1994; Brunner et al. 1994). Here, we report the characterization of a second MAP kinase in Drosophila (DJNK) that functions in an independent signal transduction pathway. The MAP kinase DINK is a homolog of the mammalian c-Jun amino-terminal protein kinase and is encoded by the gene bsk. We show that DJNK is activated during the response to endotoxic LPS. In addition, we present biochemical and genetic evidence demonstrating that DJNK participates in dorsal closure, a morphogenetic process during mid-embryogenesis that involves epithelial cell movement. Embryos deficient in DINK are unable to complete dorsal closure. Consequently, the internal organs are exposed. This defect may account for the embryonic lethality associated with $b s k$.

\section{Role of DINK in the insect immune response}

Insects secrete protective peptides in response to bacterial infection. The genes for two peptides, Cecropin and Diptericin, that are induced in response to infection contain кB-like motifs (Samakovlis et al. 1990; Reichhart et al. 1992; Engström 1993; Kappler et al. 1993). The NF$\kappa \mathrm{B}$-like protein Dif is implicated in insect immunity (Ip et al. 1993). DINK is activated in response to treatment with LPS (Fig. 6B, C) at concentrations that induce the 
protective peptide genes (Reichhart et al. 1992; Samakovlis et al. 1992; Engström et al. 1993; Kappler et al. 1993). Targets of LPS-activated DINK during the insect immune response may include DJun (Fig. 6B, C) and components of the NF-kB pathway (Hirano et al. 1996; Meyer et al. 1996). In mammalian cells, the AP-1 transcription factor (Ulevitch and Tobias 1994) and JNK (Raingeaud et al. 1995) are activated by LPS. Similarly, mammalian JNK protein kinase activity and AP-1 transcriptional activity are activated during the immune response to antigen stimulation of T cells (Su et al. 1994). By analogy, we propose that the activation of DJun by DINK in LPS-treated insect cells leads to increased AP-1 transcriptional activity. The activated Drosophila AP-1 may induce DJun expression (Zhang et al. 1990; Wang and Goldstein 1994) and other genes related to the insect immune response.

\section{Role of DINK in epithelial cell movement during embryogenesis}

A superficially similar "dorsal open" phenotype is caused by mutations in at least three different groups of genes. These genes may alter dorsoventral patterning, formation of the amnioserosa, or the epidermal cell movement during dorsal closure. The first group of genes includes members of a TGF- $\beta$-like signaling pathway, including decapentaplegic (dpp), schnurri, thick veins, saxophone, and punt (Arora et al. 1995; Grieder et al. 1995; Letsou et al. 1995; Ruberte et al. 1995). Mutations in these genes can cause severe ventralization. The second group of genes affect the formation of the amnioserosa, but not dorsoventral patterning (Jurgens et al. 1984; Ramain et al. 1993; Winick et al. 1993). The pannier gene, which encodes a GATA-like transcription factor, is representative of this class. The dorsal open phenotype caused by the third group of genes is not associated with defects in the amnioserosa or altered dorsal epidermal cell fate. Instead, these genes affect the cell shape change and movement of the lateral epithelial cells over the dorsal surface of the embryo. The hep gene represents an example of this phenotype (Glise et al. 1995).

The bsk mutants do not exhibit defects in the dorsal epidermis or amnioserosa, but do cause a severe dorsal open phenotype. The bsk phenotype is therefore similar to hep. We postulate that $b s k$, like hep, is required for cell spreading and movement during dorsal closure. A similar phenotype is observed for recessive zygotic mutations in genes of the $d p p$ signaling pathway (Arora et al. 1995; Grieder et al. 1995; Letsou et al. 1995; Ruberte et al. 1995). The $d p p$ signaling pathway therefore has both early (dorsoventral patterning) and late (dorsal closure) functions (Affolter et al. 1994). The late functions of the $d p p$ signaling pathway may be related to hep or $b s k$. However, it has been reported that bsk does not enhance the phenotype of a weak $d p p$ allele (Arora et al. 1995), indicating that these genes may act independently. Further studies are required to test these hypotheses.
Dorsal closure is regulated by a MAP kinase signal transduction pathway

Evidence obtained from genetic and molecular analyses demonstrate that DINK is a component of a MAP kinase pathway that regulates dorsal closure. First, the DINK gene maps to the $31 \mathrm{~B}-\mathrm{C}$ region on the second chromosome. Defective dorsal closure correlates with the loss of DJNK expression caused by deficiencies in the 31B-C region (Table 1). In particular, two small deficiencies, flp170B and flp147E, link DJNK function and dorsal closure. Second, genetic evidence localizes the bsk mutation to this region (Nüsslein-Volhard et al. 1984). The dorsal closure phenotype of $b s k$ is rescued by a DINK transgene (Table 2). This observation represents direct genetic evidence that bsk is a mutant allele of DINK.

Sequence analysis demonstrated the presence of a single amino acid substitution (G225E) in the DJNK gene isolated from bsk1 flies (Fig. 4D). This point mutation is located in a region of JNK that confers substrate recognition (Kallunki et al. 1994; Sluss et al. 1994; Dai et al. 1995; Gupta et al. 1996). The substitution of a neutral residue (Gly) with a charged residue (Glu) in this region may change substrate recognition by DINK and therefore the specificity of the kinase. It is also possible that the bsk1 point mutation changes the interaction of DINK with other molecules, such as a MAP kinase phosphatase. For example, the Sevenmaker gain-of-function mutation of rolled inhibits the interaction of MAP kinase phosphatase with ERKA (Bott et al. 1994).

Examination of the DJNK gene isolated from bsk2 embryos demonstrated the presence of a single point mutation in codon 316 where AAG (Lys) is replaced by TAG (Stop). This mutation causes truncation of DINK within kinase sub-domain XI (Fig. 4D). The truncated bsk2 DINK protein kinase is likely to be functionally defective. The mutant DJNK may fold improperly leading to poor stability or low activity. The presence of weak residual DINK activity in bsk2 embryos is consistent with the observation that the number of $b s k 2$ embryos showing a cuticle phenotype is less than bsk1.

The dorsal closure defect caused by loss-of-function mutations in DINK (Figs. 4 and 5) and HEP (Glise et al. 1995), together with the observation that HEP phosphorylates and activates DJNK (Fig. 6A), provides evidence for a signal transduction pathway that is required for morphogenetic cell movement during embryogenesis. Targets of DINK in the dorsal closure pathway may include the DJun transcription factor, which is expressed in the lateral epithelial cells of the embryo (Perkins et al. 1990; Zhang et al. 1990). In addition, DINK may regulate, directly or indirectly, genes required for dorsal closure, including 1(1) myospheroid ( $\beta$-integrin), zipper (nonmuscle myosin heavy chain), coracle (membrane skeleton protein), and puckered (Nüsslein-Volhard et al. 1984; MacKrell et al. 1988; Ring and Martinez Arias 1993; Young et al. 1993; Fehon et al. 1994). Additional components of the dorsal closure signaling pathway remain to be identified. However, correlative evidence suggests that a Rho-family GTPase and a PAK protein kinase par- 
ticipate as upstream elements in this signaling pathway. Mammalian JNK is activated by Rho-family GTPases that regulate the organization of the actin cytoskeleton (Bagrodia et al. 1995; Coso et al. 1995; Minden et al. 1995; Vojtek and Cooper 1995). Drosophila Rho-family GTPases (Luo et al. 1994; Harden et al. 1995; Hariharan et al. 1995) could contribute to dorsal closure during elongation of the epithelial cells by causing cytoskeletal rearrangements and/or by activating DJNK. The effect of dominant-negative DRacA to cause defective dorsal closure provides strong evidence in favor of this hypothesis (Harden et al. 1995). The Drosophila PAK protein kinase, which is expressed in the lateral epithelial cells during dorsal closure, may mediate the effects of DRacA (Harden et al. 1996). Therefore, the dorsal closure signaling pathway may include a Rho-like GTPase, the protein kinase DPAK and the MAP kinase kinase HEP, leading to the activation of the MAP kinase DJNK.

\section{Materials and methods}

Fly strains and genetic analysis

The wild-type strain was Canton $S$ (CS). The lammed-derived deficiencies (Valoir et al. 1992; Clegg et al. 1993) were obtained from T. Grigliatti (University of British Columbia, Vancouver, Canada) and $\mathrm{K}$. Beckingham (Rice University, Texas). The flp147E and $f l p 170 B$ lines were also obtained from K. Beckingham. These deletions were derived by excision of a P-element insertion in flp. Two bsk strains were obtained from NüssleinVolhard's laboratory (Max Planck Institute, Tübingen, Germany). These are stored under the names bsk[IIJ04] and bsk[IIP71], which correspond to bsk1 and bsk2, respectively (Lindsley and Zimm 1992). Another bsk1 allele was obtained from the Indiana University Stock Center. Sequence analysis demonstrated that the DJNK gene is identical in the two bsk1 alleles. P-element mediated transformation (Rubin and Spradling 1983) was done using the helper plasmid turbo $\Delta 2-3(0.1$ $\mu \mathrm{g} / \mu \mathrm{l})$ and the plasmid pCaSpeR-hsFlagDINK $(1 \mu \mathrm{g} / \mu \mathrm{l})$ that was constructed by subcloning the Flag-DINK cDNA into the BamHI and NotI sites of pCaSpeR-hs (Thummell and Pirrota 1992). The $y w^{67}$ fly used for transformation was made isogenic and does not contain any lethal mutations in the $\mathrm{X}$, second, or third chromosomes. Nine transgenic lines were obtained and balanced with the line $y w ; B c E l p / C y O ; K i / T M 6 y^{+}$. The chromosomal location of the transgenes was determined and lines with $h s D I N K$ located on the $\mathrm{X}$ or third chromosome were crossed with flies carrying the bsk or flp-derived chromosomes. The $h s D I N K$ males were crossed with double balancer females and the $\mathrm{F}_{1}+/ \mathrm{CyO}$; hsDINK/TM6y ${ }^{+}$females were collected. The $b s k$ and $f l p 170 B$ male flies were crossed with double balancer females, and the F1 bsk/Elp; $+/ T M 6 y^{+}$males collected. The $F_{1}$ flies from these two crosses were mated. The $F_{2}$ generated both female and male flies of the genotype $b s k / C y O$; $h s$. $D I N K / T M 6 y^{+}$. These were collected and mated to establish stocks.

\section{Hybridization analysis and cuticle preparation}

Embryos were dechorionated in $100 \%$ bleach, fixed, and hybridized at $55^{\circ} \mathrm{C}$ for $18 \mathrm{hr}$ (Tautz and Pfeifle 1989) to DJNK riboprobes prepared by in vitro transcription using digoxigenin-labeled uridine $-5^{\prime}$ triphosphate (UTP). The probe was detected with an anti-digoxigenin antibody conjugated to alkaline phos- phatase (Boehringer-Mannheim). Polytene salivary gland chromosomes were hybridized ( $16 \mathrm{hr}$ ) with a digoxigenin-labeled DINK probe at $37^{\circ} \mathrm{C}$. The probe was detected with a peroxidaseconjugated anti-digoxigenin antibody (Boehringer-Mannheim). Cuticle preparations were done by hand rolling the embryos to remove the chorion membrane, treatment with $85 \%$ lactic acid, and incubation at $65^{\circ} \mathrm{C}(1 \mathrm{hr})$. The embryo staining, chromosome staining, and cuticles were examined with a Zeiss Axiophot Microscope. Photographs were taken using differential interference contrast optics (embryos and cuticles) and phase-contrast optics (chromosomes).

\section{Molecular cloning of DINK}

PCR was performed using the degenerate oligonucleotides TCITC/G/A)TAIGGIGTCATC AT(G/A)AA and CCITT/T/C)CA (A/G)AA(C/T)CA(A/G)ACICA as primers (I = inosine). An embryonic (0-4 hr) cDNA library was used as the template (Brown and Kafatos 1988). The annealing temperature was $42^{\circ} \mathrm{C}$ and 35 cycles were performed. The PCR product $(200 \mathrm{bp}$ ) was subcloned into the Bluescript vector (Stratagene, Inc.) and sequenced. Full-length DINK cDNAs were isolated by screening the $0-4$ hr embryonic cDNA library with the PCR fragment as a probe. Five independent clones were obtained, four of which were full length. Genomic DJNK clones were isolated by screening an EMBL4 genomic library (Ip et al. 1993) with the DJNK cDNA. Restriction mapping and Southern analysis demonstrated that a 9-kb BamHI fragment contained all the DINKcoding region. This $B a m H I$ fragment was subcloned in the Bluescript vector (Stratagene, Inc.) and sequenced using oligonucleotide primers and a model 373A machine (Applied Biosystems, Inc.).

\section{Analysis of mutations in the DINK gene}

The embryos obtained by crossing heterozygous bsk flies were collected, aged for $24-36 \mathrm{hr}$, and dechorionated with bleach. Genomic DNA $(2-4 \mu \mathrm{g})$ from 400 bsk embryos was isolated and used to amplify the DINK genomic locus by PCR. The primer sequences were: BASK1, TACCCTCTTGAAAAGGCCGATATGCTCCTT; BASK2, TTTAGAGTGCAGTC GGCCTTTACAACTATA; BASK3, ACGTACAGTATGAATACATCTTTAAAATG; and BASK4, TCTTGTGACTGACTAAGGAGGAAAAAGTCG. The BASK1 and BASK4 primers were employed to amplify the DINK genomic region. The annealing temperature was $60^{\circ} \mathrm{C}$ and 30 cycles were performed using Pfu polymerase (Stratagene, Inc.). The PCR product was re-amplified with the primers BASK1 plus BASK2, or BASK3 plus BASK4. The PCR products were cloned and sequenced with a model $373 \mathrm{~A}$ machine (Applied Biosystems, Inc.). The sequence of the DINK gene obtained from four independent PCR reactions was identical.

\section{Expression and purification of recombinant proteins}

The DJNK cDNA was sub-cloned into the pGSTag vector (Dressler and Ron 1992) at the BamHI and SacI sites. An expression vector for GST-DJun (residues 1-104) was constructed by sub-cloning a PCR fragment of the DJun gene into the BamHI and EcoRI sites of pGEX-3X (Pharmacia-LKB Biotechnology, Inc.). A vector for GST-HEP was constructed by subcloning a HEP cDNA (obtained by reverse-transcriptase PCR amplification of poly(A) ${ }^{+}$RNA obtained from 0- to 12-hr Drosophila embryos) into the BamHI and EcoRI sites of pGEX-5X-1 (Pharmacia-LKB Biotechnology, Inc.). The plasmids were se- 
quenced with an Applied Biosystems model 373A machine. The fusion proteins were purified by affinity chromatography (Smith and Johnson 1988).

\section{In vitro protein kinase assays}

Recombinant DJNK $(1 \mu \mathrm{g})$, HEP $(1 \mu \mathrm{g})$ and DJun $(2 \mu \mathrm{g})$ were incubated in $20 \mu$ l of kinase buffer [ $20 \mathrm{mM}$ HEPES (pH 7.6), 20 $\mathrm{mM} \mathrm{MgCl} 2,2 \mathrm{~mm}$ dithiothreitol, $25 \mathrm{mM} \beta$-glycerophosphate, 0.1 mM Na orthovanadate $]$ with $20 \mu \mathrm{M}\left[\gamma^{-}{ }^{32} \mathrm{P}\right] \mathrm{ATP}(10 \mathrm{Ci} / \mathrm{mmole})$. The phosphorylation reaction was terminated after $10 \mathrm{~min}$ and examined by polyacrylamide gel electrophoresis (PAGE) and autoradiography.

\section{Characterization of DINK in insect cells}

The $m b n-2$ cells were maintained in $1 \times$ Drosophila Schneider Medium (GIBCO-BRL) supplemented with $10 \%$ heat-inactivated fetal calf serum (Hyclone, Inc.). LPS (Escherichia coli 055:B5, Sigma) was added $(10 \mu \mathrm{g} / \mathrm{ml})$, the cells incubated for various times at $23^{\circ} \mathrm{C}$ and harvested in Triton lysis buffer [20 mM Tris (pH 7.4), $137 \mathrm{~mm} \mathrm{NaCl}, 2 \mathrm{~mm}$ EDTA, $1 \%$ Triton X-100, $10 \%$ glycerol, $2 \mathrm{~mm}$ Na pyrophosphate, $25 \mathrm{~mm} \beta$-glycerophosphate, $1 \mathrm{mM} \mathrm{Na}$ orthovanadate, leupeptin $(10 \mu \mathrm{g} / \mathrm{ml})$, and $1 \mathrm{mM}$ phenylmethylsulfonyl fluoride]. Protein concentration was measured using the BCA assay kit (Pierce Chemical Co.). Endogenous DINK was purified by immunoprecipitation of cell extracts $(500 \mu \mathrm{g})$ with $5 \mu \mathrm{l}$ of a rabbit antibody to JNK prebound to protein A-Agarose (Sluss et al. 1994). The immunoprecipitates were washed four times with HEPES-binding buffer [HB; $20 \mathrm{~mm}$ HEPES (pH 7.4), $50 \mathrm{~mm} \mathrm{NaCl}, 0.1 \mathrm{~mm}$ EDTA, $25 \mathrm{~mm}$ $\mathrm{MgCl}_{2}$, and $0.05 \%$ Triton X-100] and once with kinase buffer. The immune complex was resuspended in $25 \mu$ l of kinase buffer with $20 \mu \mathrm{M}\left[\gamma^{32} \mathrm{P}\right] \mathrm{ATP}(10 \mathrm{Ci} / \mathrm{mmole})$ and $5 \mu \mathrm{g}$ of substrate protein (GST-DJun). The reaction was terminated after $10 \mathrm{~min}$ and the products were examined by PAGE and autoradiography.

\section{Expression of DINK in insect cells}

Epitope-tagged DINK was created by PCR using primers containing $5^{\prime}$ BamHI and 3' SacI restriction sites. The Flag sequence (Immunex Corp.) was inserted between codons 1 and 2 of DINK. The PCR product was subcloned in the BamHI and Sacl sites of the pAcPA vector, which contains the Actin 5C promoter. Schneider $\mathrm{S} 2{ }^{\star}$ cells were maintained and transfected with the pAcPA expression vector, as described (Han and Manley 1993). The cells were harvested $24 \mathrm{hr}$ post-transfection in Triton lysis buffer. An aliquot was removed for Western blot analysis using the M2 (anti-Flag) monoclonal antibody (IBIKodak). The remainder of the lysate was incubated with the M2 antibody prebound to protein G-Agarose. The immune complexes were washed with HB buffer and kinase buffer. Immune complex kinase assays were done with the substrate GSTDIun.

\section{Acknowledgments}

We thank N. Perrimon for the DJun genomic clone; K. Beckingham for flp - and Jammed - lines; T. Grigliatti for Jammed-lines; S. Small, T. Maniatis, and Y. Engström for tissue culture cells; E. Baehrecke, R. Jackson, and W. Gelbart for help with the chromosome in situ analysis; B. Khanuja and I.-H. Wu for expert technical assistance; members of the Ip and Davis laboratories for support; and E. Hafen, K. Beckingham, and C. Wilson for discussions. This study was supported, in part, by National Institutes of Health grants GM53269 (to Y.T.I.) and
CA65861 (to R.J.D.). Y.T.I. was supported by grants from the American Cancer Society (Massachusetts Division) and Lucille P. Markey Charitable Trust. R.J.D. is an investigator of the Howard Hughes Medical Institute.

The publication costs of this article were defrayed in part by payment of page charges. This article must therefore be hereby marked "advertisement" in accordance with 18 USC section 1734 solely to indicate this fact.

\section{Note}

The sequence of the DINK cDNA, DJNK gene, bskl gene, and $b s k 2$ gene have been deposited in the GenBank data library under the accession nos. U49180, U49249, U50965, and U50966, respectively.

\section{References}

Affolter, M., D. Nellen, U. Nussbaumer, and K. Basler. 1994. Multiple requirements for the receptor serine/threonine kinase thick veins reveal novel functions of TGF beta homologues during Drosophila embryogenesis. Development 120: 3105-3117.

Arora, K., H. Dai, S.G. Kazuko, J. Jamal, M.B. O'Connor, A. Letsou, and R. Warrior. 1995.. The Drosophila schnurri gene acts in the Dpp/TGF $\beta$ signaling pathway and encodes a transcription factor homologous to the human MBP family. Cell 81: 781-790.

Ashburner, M. 1989. Drosophila: A laboratory manual. Cold Spring Harbor Laboratory Press, Cold Spring Harbor, NY.

Bagrodia, S., B. Derijard, R.J. Davis, and R. Cerione. 1995. Cdc42 and PAK-mediated signaling leads to JNK and p38 MAP kinase activation. I. Biol. Chem. 270: 27995-27998.

Biggs, W.H. and S.L. Zipursky. 1992. Primary structure, expression, and signal-dependent tyrosine phosphorylation of a Drosophila homolog of extracellular signal-regulated kinase. Proc. Natl. Acad. Sci. 89: 6295-6299.

Biggs, W.H., K.H. Zavitz, B. Dickson, A. van der Straten, D. Brunner, E. Hafen, and S.L. Zipursky. 1994. The Drosophila rolled locus encodes a MAP kinase required in the sevenless signal transduction pathway. EMBO J. 13: 1628-1635.

Bott, C.M., S.G. Thornercroft, and C.J. Marshall. 1994. The sevenmaker gain-of-function mutation in p42 MAP kinase leads to enhanced signaling and reduced sensitivity to dual specificity phosphatase action. FEBS Letts. 352: 201-205.

Brown, N.H. and F.C. Kafatos. 1988. Functional cDNA libraries from Drosophila embryos. J. Mol. Biol. 203: 425-437.

Brunner, D., N. Oellers, J. Szabad, W.H. Biggs, S.L. Zipursky, and E. Hafen. 1994. A gain-of-function mutation in Drosophila MAP kinase activates multiple receptor tyrosine kinase signaling pathways. Cell 76: $875-888$.

Cavigelli, M., F. Dolfi, F.-X. Claret, and M. Karin. 1995. Induction of c-fos expression through INK-mediated TCF/Elk-1 phosphorylation. EMBO J. 14: 5957-5964.

Chen, Y.-R., C.F. Meyer, and T.-H. Tan. 1996. Persistent activation of c-Jun N-terminal kinase 1 JNK1 in $\gamma$ radiationinduced apoptosis. J. Biol. Chem. 271: 631-634.

Clegg, N.J., I.P. Whitehead, J.K. Brock, D.A. Sinclair, R. Mottus, G. Stromotich, M.J. Harrington, and T.A. Grigliatti. 1993. A cytogenetic analysis of chromosome region 31 of Drosophila melanogaster. Genetics 134: 221-230.

Coso, O.A., M. Chiariello, J.-C. Yu, H. Teramoto, P. Crespo, N. Xu, T. Miki, and J.S. Gutkind. 1995. The small GTP-binding proteins racl and cdc42 regulate the activity of the JNK/ SAPK signaling pathway. Cell 81: 1137-1146. 
Dai, T., E. Rubie, C.C. Franklin, A. Kraft, D.A. Gillespie, J. Avruch, J.M. Kyriakis, and J.R. Woodgett. 1995. Stress-activated protein kinases bind directly to the delta domain of c-Jun in resting cells: Implications for repression of c-Jun function. Oncogene 10: 849-855.

Davis, R.J. 1994. MAP kinases: New JNK expands the group. Trends Biochem. Sci. 19: 470-473.

Dérijard, B., M. Hibi, I.-H. Wu, T. Barrett, B. Su, T. Deng, M. Karin, and R.J. Davis. 1994. JNK1: A protein kinase stimulated by UV light and Ha-Ras that binds and phosphorylates the c-Jun activation domain. Cell 76: 1025-1037.

Dérijard, B., J. Raingeaud, T. Barrett, I.-H. Wu, J. Han, R.J. Ulevitch, and R.J. Davis. 1995. Independent human MAP kinase signal transduction pathways defined by MEK and MKK isoforms. Science 267: 682-685.

Dressler, H. and D. Ron. 1992. pGSTag-a versatile bacterial expression plasmid for enzymatic labelling of recombinant proteins. BioTechniques 13: 866-869.

Engström, Y. 1993. Insect immune systems. In Insect molecular science (ed. J.M. Campton and P. Eggleston), pp. 125-137. Academic Press, London, UK.

Engström, Y., L. Kadalayil, S.C. Sun, C. Samakovlis, D. Hultmark, and I. Faye. 1993. кB-like motifs regulate the induction of immune genes in Drosophila. J. Mol. Biol. 232: 327333.

Fehon, R.G., I.A. Dawson, and S. Artavanis-Tsakonas. 1994. A Drosophila homologue of membrane skeleton protein 4.1 is associated with septate junctions and is encoded by the coracle gene. Development 120: 545-557.

Gille, H., T. Strahl, and P.E. Shaw. 1995. Activation of ternary complex factor Elk-1 by stress-activated protein kinases. Curr. Biol. 5: 1191-1200.

Glise, B., H. Bourbon, and S. Noselli. 1995. hemipterous encodes a novel MAP kinase kinase required for epithelial cell sheet movement. Cell 83: 451-461.

Gonzalez, F.A., D.L. Raden, M.R. Rigby, and R.J. Davis. 1992. Heterogeneous expression of four MAP kinase isoforms in human tissues. FEBS Lett. 304: 170-178.

Grieder, N.C., D. Nellen, R. Burke, K. Basler, and M. Affolter. 1995. schnurri is required for Drosophila Dpp signaling and encodes a zinc finger protein similar to the mammalian transcription factor PRDII-BF1. Cell 81: 791-800.

Gupta, S., D. Campbell, B. Dérijard, and R.J. Davis. 1995. Transcription factor ATF2 regulation by the JNK signal transduction pathway. Science 267: 389-393.

Gupta, S., T. Barrett, A.J. Whitmarsh, J. Cavanagh, H.K. Sluss, B. Dérijard, and R.J. Davis. 1996. Selective interaction of JNK protein kinase isoforms with transcription factors. $E M B O$ I. 15: 2760-2770.

Han, J., B. Richter, Z. Li, V. Kravchenko, and R.J. Ulevitch. 1995. Molecular cloning of human p38 MAP kinase. Biochim. Biophys. Acta 265: 224-227.

Han, K. and J.L. Manley. 1993. Transcriptional repression by the Drosophila even-skipped protein: Definition of a minimal repression domain. Genes \& Dev. 7: 491-503.

Harden, N., H.Y. Loh, W. Chia, and L. Lim. 1995. A dominant inhibitory version of the small GTP-binding protein Rac disrupts cytoskeletal structures and inhibits developmental shape changes in Drosophila. Development 121: 903-914.

Harden, N., J. Lee, H.-Y. Loh, Y.-M. Ong, I. Tan, T. Leung, E. Manser, and L. Lim. 1996. A Drosophila homolog of the Racand Cdc42-activated serine/threonine kinase PAK is a potential focal adhesion and focal complex protein that colocalizes with dynamic actin structures. Mol. Cell. Biol. 16: 1896-1980.

Hariharan, I.K., K.-Q. Hu, H. Asha, A. Quintanilla, R.M. Ezzell, and J. Settleman. 1995. Characterization of rho GTPase family homologues in Drosophila melanogaster: Over-expressing Rhol in retinal cells causes a late developmental defect. EMBO I. 14: 292-302.

Hirano, M., S. Osada, T. Aoki, S. Hirai, M. Hosaka, J. Inoue, and S. Ohno. 1996. MEK kinase is involved in tumor necrosis factor $\alpha$-induced NF- $\mathrm{BB}$ activation and degradation of IкB- $\alpha$. J. Biol. Chem. 271: 13234-13238.

Hoffmann, J.A., C. Hetru, and J.M. Reichhart. 1993. The humoral antibacterial response of Drosophila. FEBS Lett. 325: 63-66.

Hultmark, D. 1993. Immune reactions in Drosophila and other insects: A model for innate immunity. Trends. Genet. 9: $178-183$.

Ip, Y.T. and M. Levine. 1994. Molecular genetics of Drosophila immunity. Curr. Opin. Genet. Dev. 4: 672-677.

Ip, Y.T., M. Reach, Y. Engström, L. Kadalayil, H. Cai, S. Gonzalez-Crespo, K. Tatei, and M. Levine. 1993. Dif, a dorsal-related gene that mediates an immune response in Drosophila. Cell 75: 753-763.

Jurgens, G., E. Wieschaus, C. Nusslein-Volhard, and H. Kluding. 1984. Mutations affecting the pattern of the larval cuticle in Drosophila melanogaster II. Zygotic loci on the third chromosome. Roux's Arch. Dev. Biol. 193: 283-295.

Kallunki, T., B. Su, I. Tsigelny, H.K. Sluss, B. Dérijard, G. Moore, R.J. Davis, and M. Karin. 1994. JNK2 contains a specificity-determining region responsible for efficient c-Jun binding and phosphorylation. Genes \& Dev. 8: 2996-3007.

Kappler, C., M. Meister, M. Lagueux, E. Gateff, J.A. Hoffmann, and J.-M. Reichhart. 1993. Insect immunity. Two 17 bp repeats nesting a $\kappa \mathrm{B}-$ related sequence confer inducibility to the diptericin gene and bind a polypeptide in bacteria-challenged Drosophila. EMBO J. 12: 1561-1568.

Kyriakis, J.M., P. Banerjee, E. Nikolakaki, T. Dai, E.A. Rubie, M.F. Ahmad, J. Avruch, and J.R. Woodgett. 1994. The stressactivated protein kinase subfamily of c-Jun kinases. Nature 369: 156-160.

Lee, J.C., J.T. Laydon, P.C. McDonnell, T.F. Gallagher, S. Kumar, D. Green, D. McNulty, M.J. Blumenthal, J.R. Heys, S.W. Landvatter, J.E. Strickler, M.M. McLaughlin, I.R. Siemens, S.M. Fisher, G.P. Livi, J.R. White, J.L. Adams, and P.R. Young. 1994. A protein kinase involved in the regulation of inflammatory cytokine biosynthesis. Nature 327: 739-746.

Letsou, A., K. Arora, J.L. Wrana, K. Simin, V. Twombly, J. Jamal, K. Staehling-Hampton, M.F. Hoffmann, W.M. Gelbart, J. Massague, and M.B. O'Connor. 1995. Drosophila Dpp signaling is mediated by the punt gene product: A dual ligandbinding type II receptor of the TGF $\beta$ receptor family. Cell 80: 899-908.

Lin, A., A. Minden, H. Martinetto, F.-X. Claret, C. Lange-Carter, F. Mercurio, G.L. Johnson, and M. Karin. 1995. Identification of a dual specificity kinase that activates Jun kinases and p38-Mpk2. Science 268: 286-290.

Lindsley, D.L. and G.G. Zimm. 1992. The genome of Drosophila melanogaster. Academic Press, San Diego, CA.

Livingstone, C., G. Patel, and N. Jones. 1995. ATF-2 contains a phosphorylation-dependent transcriptional activation domain. EMBO J. 14: 1785-1797.

Luo, L., Y.J. Liao, L.Y. Jan, and Y.N. Jan. 1994. Distinct morphogenetic functions of similar small GTPases: Drosophila Dracl is involved in axonal outgrowth and myoblast fusion. Genes \& Dev. 8: 1787-1802.

MacKrell, A.J., B. Blumberg, S.R. Haynes, and J.H. Fessler. 1988. The lethal myospheroid gene of Drosophila encodes a membrane protein homologous to vertebrate integrin beta subunits. Proc. Nat1. Acad. Sci. 85: 2633-2637. 
Meyer, C.F., X. Wang, C. Chang, D. Templeton, and T.-H. Tan. 1996. Interaction between c-Rel and the mitogen-activated protein kinase kinase 1 signaling cascade in mediating $\mathrm{kB}$ enhancer activation. J. Biol. Chem. 271: 8971-8976.

Minden, A., A. Lin, F.-X. Claret, A. Abo, and M. Karin. 1995. Selective activation of the JNK signaling cascade and c-Jun transcriptional activity by the small GTPases Rac and Cdc42Hs. Cell 81: 1147-1157.

Mohit, A.A., J.H. Martin, and C.A. Miller. 1995. p49 ${ }^{3 F 12}$ : A novel MAP kinase expressed in a subset of neurons in the human nervous system. Neuron 14: 67-78.

Nüsslein-Volhard, C., E. Wieschaus, and H. Kluding. 1984. Mutations affecting the pattern of the larval cuticle in Drosophila melanogaster. I. Zygotic loci on the second chromosome. Wilhelm Roux's Arch. Dev. Biol. 193: 267-282.

Owaki, H., R. Makar, T.G. Boulton, M.H. Cobb, and T.D. Geppert. 1992. Extracellular signal-regulated kinases in T cells: Characterization of human ERK1 and ERK2 cDNAs. Bioch. \& Biophys. Res. Comm. 182: 1416-1422.

Perkins, K.K., G.M. Dailey, and R. Tijan. 1988. Novel Jun- and Fos- related proteins in Drosophila are functionally homologous to enhancer factor AP-1. EMBO J. 13: 4265-4273.

Perkins, K.K., A. Admon, N. Patel, and R. Tjian. 1990. The Drosophila Fos-related transcription factor AP-1 protein is a developmentally regulated transcription factor. Genes \& Dev. 4: 822-834.

Petersen, U.-M., G. Bjorklund, Y.T. Ip, and Y. Ëngstrom. 1995. The dorsal-related immunity, Dif, is a sequence-specific trans-activator of Drosophila Cecropin gene expression. EMBO /. 14: 3146-3158.

Pulverer, B.J., J.M. Kyriakis, J. Avruch, E. Nikolakaki, and J.R. Woodgett. 1991. Phosphorylation of c-Jun mediated by MAP kinases. Nature 353: 670-674.

Raingeaud, J., S. Gupta, J.S. Rogers, M. Dickens, J. Han, R.J. Ulevitch, and R.J. Davis. 1995. Pro-inflammatory cytokines and environmental stress cause p38 mitogen-activated protein kinase activation by dual phosphorylation on tyrosine and threonine. J. Biol. Chem. 270: 7420-7426.

Raingeaud, J., A. Whitmarsh, T. Barrett, B. Dérijard, and R.J. Davis. 1996. MKK3- and MKK6-regulated gene expression is mediated by the p38 mitogen activated protein kinase signal transduction pathway. Mol. Cell. Biol. 16: 1247-1255.

Ramain, P., P. Heitzler, M. Haenlin, and P. Simpson. 1993. pannier, a negative regulator of achaete and scute in Drosophila, encodes a zinc finger protein with homology to the vertebrate transcription factor GATA-1. Development 119: 12771291.

Reichhart, J.M., M. Meister, J.L. Dimarq, D. Zachary, D. Hoffman, C. Ruiz, G. Richards, and J.A. Hoffman. 1992. Insect immunity: Developmental and inducible activity of the Drosophila diptericin promoter. EMBO J. 11: 1469-1477.

Ring, J.M. and A.M. Martinez Arias. 1993. puckered, a gene involved in position specific differentiation in the dorsal epidermis of the Drososphila larva. Development (Suppl.): 251259.

Ruberte, E., T. Marty, D. Nellen, M. Affolter, and K. Basler. 1995. An absolute requirement for both the type II and type I receptors, punt and thick veins, for dpp signaling in vivo. Cell 80: 889-897.

Rubin, G. and A. Spradling. 1983. Vectors for P-element-mediated gene transfer in Drosophila. Nucleic Acids Res. 11: 6341-6351.

Samakovlis, C., B. Asling, P. Kylsten, A. Engström, and D. Hultmark. 1990. The immune response in Drosophila: Pattern of cecropin expression and biological activity. EMBO $J$. 9: 2969-2976.
Samakovlis, C., B. Asling, H.G. Boman, E. Gateff, and D. Hultmark. 1992. In vitro induction of cecropin genes-An immune response in a Drosophila blood cell line. Biochem. 4$)$ Biophys. Res. Comm. 188: 1169-1175.

Sanchez, I., R.T. Hughes, B.J. Mayer, K. Yee, J.R. Woodgett, J. Avruch, J.M. Kyriakis, and L.I. Zon. 1994. Role of SAPK/ ERK kinase-1 in the stress-activated pathway regulating transcription factor c-Jun. Nature 372: 794-798.

Sluss, H.K., T. Barrett, B. Dérijard, and R.J. Davis. 1994. Signal transduction by tumor necrosis factor mediated by JNK protein kinases. Mol. Cell. Biol. 14: 8376-8384.

Smeal, T., B. Binetruy, D.A. Mercola, M. Birrer, and M. Karin. 1991. Oncogenic and transcriptional cooperation with HaRas requires phosphorylation of c-Jun on serines 63 and 73 . Nature 354: 494-496.

Smith, S.B. and K.S. Johnson. 1988. Single-step purification of polypeptides expressed in Eschericia coli as fusions with glutathione-S-transferase. Gene 67: 31-40.

Stein, B., H.J. Rahmsdorf, A. Steffen, M. Litfin, and P. Herrlich. 1989. UV-induced DNA damage is an intermediate step in UV-induced expression of human immunodeficiency virus type 1, collagenase, c-fos, and metallothionein. Mol. Cell. Biol. 9: 5169-5181.

Steward, R. and S. Govind. 1993. Dorsal-ventral polarity in the Drosophila embryo. Curr. Opin. Gen. Dev. 3: 556-561.

Su, B., E. Jacinto, M. Hibi, T. Kallunki, M. Karin, and Y. BenNeriah. 1994. JNK is involved in signal integration during costimulation of T lymphocytes. Cell 77: 727-736.

Tautz, D. and C. Pfeifle. 1989. A non-radioactive in situ hubridization method for the localization of specific mRNAs in Drosophila embryos reveals translational control of the segmentation gene hunchback. Chromosoma 98: 81-85.

Thummell, C.S. and Y. Pirrota. 1992. New pCaSpeR P-element vectors. Dros. Inf. Serv. 71: 150.

Ulevitch, R.J. and P.S. Tobias. 1994. Recognition of endotoxin by cells leading to transmembrane signaling. Curr. Opin. Immunol. 6: 125-130.

Valoir, T., M.A. Tucker, E.J. Belikoff, L.A. Camp, C. Bolduc, and K. Beckingham. 1992. A second maternally expressed Drosophila gene encodes a putative RNA helicase of the "Dead box" family. Proc. Nat. Acad. Sci. 88: 2113-2117.

van Dam, H., D. Wilhelm, I. Herr, A. Steffen, P. Herrlich, and P. Angel. 1995. ATF2 is preferentially activated by stress-activated protein kinases to mediate c-Jun induction in response to genotoxic agents. EMBO J. 14: 1798-1811.

Verheij, M., R. Bose, X.H. Lin, B. Yao, D. Jarvis, S. Grant, M.J. Birrer, E. Szabo, L.I. Zon, J.M. Kyriakis, A. Haimovitz-Friedman, Z. Fuks, and R.N. Kolesnick. 1996. Requirement for ceramide-initiated SAPK/JNK signaling in stress-induced apoptosis. Nature 380: 75-79.

Verma, I.M., J.K. Stevenson, E.M. Schwarz, D. Van Antwerp, and S. Miyamoto. 1995. Rel/NFkB/IкB family: Intimate tales of association and dissociation. Genes \& Dev. 9: 27232735.

Voitek, A.B. and J. Cooper. 1995. Rho family members: Activators of MAP kinase cascades. Cell 82: 527-529.

Wang, G.L. and E.S. Goldstein. 1994. Transcription of DJun from D. melanogaster is positively regulated by DTF-1, AP1, and CREB binding sites. Exp. Cell Res. 1: 389-399.

Westwick, J.K., C. Weitzel, A. Minden, M. Karin, and D.A. Brenner. 1994. Tumor necrosis factor alpha stimulates AP-1 activity through prolonged activation of the c-Jun kinase. $I$. Biol. Chem. 269: 26396-26401.

Whitmarsh, A.J., P. Shore, A.D. Sharrocks, and R.J. Davis, 1995. Integration of MAP kinase signal transduction at the serum response element. Science 269: 403-407. 
Sluss et al.

Wilson, C., D.C.I. Goberdhan, and H. Steller. 1993. Dror, a potential neurotrophic receptor gene, encodes a Drosophila homolog of the vertebrate Ror family of Trk-related receptor tyrosine kinases. Proc. Natl. Acad. Sci. 90: 7109-7113.

Winick, J., T. Abel, M.W. Leonard, A.M. Michelson, I. ChardonLoriaux, R.A. Holmgren, T. Maniatis, and J.D. Engel. 1993. A GATA family transcription factor is expressed along the embryonic dorsoventral axis in Drosophila melanogaster. Development 119: 1055-1065.

Xia, Z., M. Dickens, J. Raingeaud, R.J. Davis, and M.E. Greenberg. 1995. Opposing effects of ERK and JNK-p38 MAP kinases on apoptosis. Science 270: 1326-1331.

Young, P., A.M. Richman, A.S. Ketchum, and D.P. Kiehart. 1993. Morphogenesis in Drosophila requires nonmuscle myosin heavy chain function. Genes \& Dev. 7: 29-41.

Zhang, K., J.R. Chaillet, L.A. Perkins, T.D. Halazonetis, and N. Perrimon. 1990. Drosophila homolog of the mammalian iun oncogene is expressed during embryonic development and activates transcription in mammalian cells. Proc. Nat. Acad. Sci. 87: 6281-6285. 


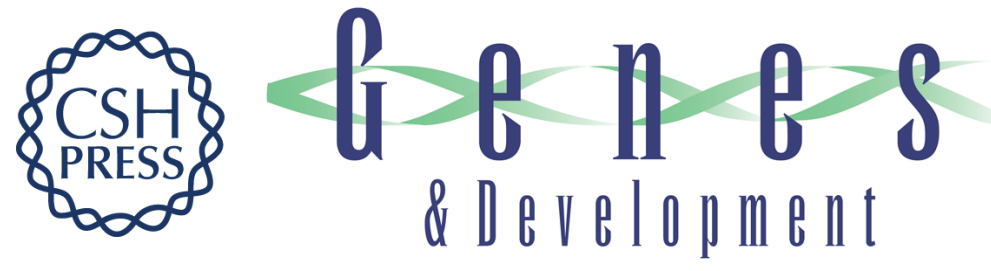

\section{A JNK signal transduction pathway that mediates morphogenesis and an immune response in Drosophila.}

H K Sluss, Z Han, T Barrett, et al.

Genes Dev. 1996, 10:

Access the most recent version at doi:10.1101/gad.10.21.2745

References This article cites 85 articles, 30 of which can be accessed free at:

http://genesdev.cshlp.org/content/10/21/2745.full.html\#ref-list-1

License

Email Alerting

Service

Receive free email alerts when new articles cite this article - sign up in the box at the top right corner of the article or click here.

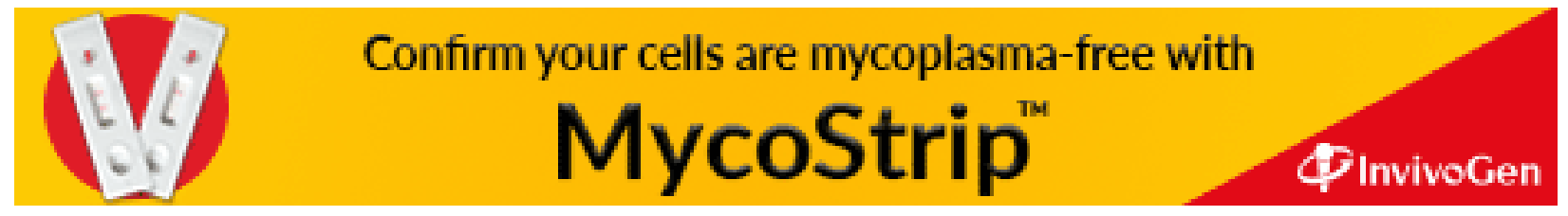

